\title{
Proposing a Method for Assessing Fuel Consumption and Pollutants Emissions with the Use of Continuously Variable Transmission in Town Cars
}

\author{
Leonardo Serfert Junior ${ }^{12^{*}}$, Thiago B. Muraria ${ }^{2}$, Lilian Lefol Nani Guarieiro ${ }^{1}$ \\ ${ }^{1}$ Senai Cimatec University Center; Salvador, Bahia; ${ }^{2}$ Ford Motor Company Brasil; Camaçari, Bahia, Brazil
}

\begin{abstract}
The $21^{\text {st }}$ century brings countless social, economic, environmental, and technological challenges to humanity and, to face them, the United Nations (UN) created the Sustainable Development Goals (SDGs). The auto industry, which is part of the private sector, aims to reach them. In this context, this study aims to evaluate the consumption and emissions of pollutants by using an automatic transmission of the CVT (Continuously Variable Transmission) type concerning the automatic transmission of the "Planetary" type. This study will be based on the Consumption/Energy Efficiency tables, published annually by INMETRO (National Institute of Metrology, Quality, and Technology) and whose data will be processed and evaluated using the Quik Sense Software. Thus, the work aims to appraise the advantages of vehicles with automatic transmission of the CVT type about fuel consumption, energy efficiency and emissions, in markets such as Brazil, where these vehicles use ethanol or a mixture of gasoline with up to 27 as fuel \% Ethanol. This research can contribute to studies of emission control and approval, benefiting the automotive industry in general, government agencies, the environment, the economy, and society, contributing to the UN's SDGs achievement.
\end{abstract}

Keywords: Emissions. Consumption. CVT. Transmission by Planetary. Energy Efficiency. Sustainable Development.

\section{Introduction}

Nowadays, research and development of quality products that meet the demands of consumers are essential, in addition to the broad competition in the market and the relevant legislation (Route 2030: Law No. 13,755). In addition, these products must be within the Goals for Achieving Sustainable Development (SDG), included in the 2030 Agenda of the United Nations (UN), which Brazil ratified.

The Sustainable Development Goals (SDGs) belong to a global agenda, adopted during the United Nations Summit on Sustainable Development, in September 2015, comprising 17 objectives and 169 goals to be achieved by 2030 (UN, 2015). This agenda includes global actions in the areas of poverty eradication, food security, agriculture, health, education, gender

Received on 23 August 2021; revised 15 September 2021. Address for correspondence: Leonardo Serfert Junior. SENAI CIMATEC. Avenida Orlando Gomes, Número 1845 - Piatã, Zip Code: 41650-010, Salvador, Bahia, Brazil. E-mail: lserfert@ford.com.

J Bioeng. Tech. Appl. Health 2021;4(4):134-140.

(C) 2021 by SENAI CIMATEC. All rights reserved. equality, reduction of inequalities, energy, water and sanitation, sustainable patterns of production and consumption, climate change, sustainable cities, protection, and sustainable use of oceans and terrestrial ecosystems, inclusive economic growth, infrastructure, industrialization, among others (UN, 2015). Among the 17 SDGs, three are directly impacted by urban mobility and the use of motor vehicles.

The SDG 03 "Good Health and Well-being" aims "To ensure a healthy life and promote wellbeing for all, at all ages" Within its objectives is the target 3.9: "By 2030, substantially reduce the number of deaths and diseases from dangerous chemicals, contamination and pollution of air, water and the soil", which this work will seek to contribute when offering proof of which transmission will pollute less.

The SDG 01," Sustainable Cities and Communities", seeks to "Make cities and human settlements inclusive, safe, resilient and sustainable. " Its goal 11.6: "By 2030, reduce the negative environmental impact per capita of cities, including paying special attention to air quality, municipal waste management, and others; " and, in particular, submit 11.6.2 "Average annual level of inhalable particles (e.g. with particulate 
diameter less than $2.5 \mu \mathrm{m}$ and $10 \mu \mathrm{m}$ ) in cities (weighted population)", which are also targets of the contribution of this study.

And SDG 13, "Action Against Global Climate Change", seeks to "take urgent action to combat climate change and its impacts". Within this objective, goal 13.2: "Integrate climate change measures into national policies, strategies, and planning"; and its goal 13.2.2: "Total greenhouse gas emissions per year"; which are united nations determinations that this research aims to privilege, through the use of a more efficient product by the consumer.

A solution to reduce fuel consumption and pollutant gas emissions in automatic transmission vehicles is the Continuously Variable Transmission (CVT), imagined by Leonardo da Vinci more than 500 years ago, which can simulate an infinite amount of gait relationships. It contains a system of two pulleys of different sizes, which are interconnected by a high-strength metal belt, rather than gears with certain sizes (Beltrão, 2015).

There is a consensus that a CVT transmission presents an advantage with fuel consumption when compared to automatic planetary transmissions. This is since CVT has a "continuous" gear shift, making it possible to keep the engine working in "optimal" regions of torque and power [14].

In a CVT transmission, torque transfer is done by friction between a belt and two pulleys. The torque transmission capacity of the CVT is directly related to the axial forces of the primary and secondary pulleys. These forces are the result of hydraulic pressure from the transmission pumping system. This hydraulic pressure plus the friction of the metal belt with the pulleys are the main points of efficiency losses: oil pump / hydraulic actuation system that works between 50 and 70 bar (a Planetary automatic transmission is less than half of this pressure) and the very high friction torque transmission (to prevent slipping). Thus, the efficiency of a CVT is $10 \%$ to $-20 \%$ lower than an automatic transmission by planetary [6].

It is important to note that, in a continuously variable transmission (CVT), the ratio changes between its maximum and minimum values (Span), a characteristic that disassociates the engine's speed (rotation) from the vehicle's speed. This feature allows an additional degree of freedom to accompany the ideal engine operation line (OOL- Optimal Operation Line) and thus operate in a region of greater efficiency. However, for automatic transmission by planetary gears, which have defined gears ("gear sets"), gear changes can only contribute to the operation of the engine in areas "close" to its ideal region. This difference between them allows an improvement of $5 \%$ to $15 \%$ in fuel economy for a vehicle with CVT transmission - when we compared a vehicle with automatic transmission for planetary (stepped gears). Especially when the maximum speed of the vehicle is relatively low; we observed that the improvement in fuel economy is more significant [14].

In addition, as the number of gears ("gear sets") of an automatic planetary transmission increases and the interval decreases, such as an $8 / 9$ or 10 -speed transmission, the influence of the types of "gear changes" (planetary staggered and continuously variable) in the efficiency of the engine operation is reduced. In addition, the improved fuel economy of CVT vehicles became not very clear, as the efficiency of the planetary transmission is higher due to its lower hydraulic loss. [14].

In this context, the objective of this project will be to compare CVT automatic transmissions with automatic planetary transmissions in vehicles sold in Brazil using E27 and E100 fuels and INMETRO approval data for consumption and emissions and to analyze the best correlation methodology. Thus, the development of this research can contribute to the goals of SDGs 03,11, and 13 and the Brazilian "NDC" ("Contribuições Nacionalmente Determinadas", like Rota 2030), which can bring more savings to the consumer and contribute to the sustainable development of the planet. To exemplify, we present the Graphic 1 of the "sawtooth diagram", in which the scale of a manual transmission (planetary transmissions 
presents a similar behave) can be compared with a "smoother curve" of a CVT transmission.

\section{Materials and Methods}

We did a bibliographic search to identify the results of studies that evaluate: fuel consumption as a reason for choosing CVT transmission to equip vehicles; comparisons of types of automatic transmissions regarding fuel consumption and atmospheric emissions, and efficiency studies of CVT transmissions.

We used the data about consumption and emissions from back 2011 through the annual publication of vehicle homologation issued by INMETRO (National Institute of Metrology, Quality and Technology - "Instituto Nacional de Metrologia, Qualidade eTecnologia")[11]. The choice of the "Fuel consumption/energy efficiency table for automotive vehicles", applied by INMETRO for vehicles sold in Brazil, is due to the standardization of data from various sources (automakers), such as the same test procedures. Results are shown in $\mathrm{km} / 1$ (kilometers per liter) taken under the same standard laboratory conditions (NBR7024) and adjusted for the most common simulated conditions of use(applications). We tabulated this data in an excel spreadsheet, selecting vehicles and engines of most commercialized versions; excluding manual, hybrid, and automated transmissions. We also excluded diesel engines and vehicles of specific applications (sports and off-road use), focusing on CVT and planetary transmissions and gasoline and flexible engines with a maximum displacement capacity of 2.0 liters and with torque and power numbers within a specific range (Table 1).

\section{Results and Discussion}

Using the "Qlick Sense" software for the consumption, efficiency, and emissions data, from the sample resulting from the tabulation, we can understand the collective behavior of each type of transmission studied (planetary and Continuously Variable). The analysis, also, has been validated by statistical reviews and comparisons. Finally, we create a dashboard per cluster system to understand the collective behavior of each type of transmission, associated with the type of fuels and engines applications (Graphics 2 and 3).

Graphic 1. Sawtooth diagram (Manual transmission and CVT "smoother curve).

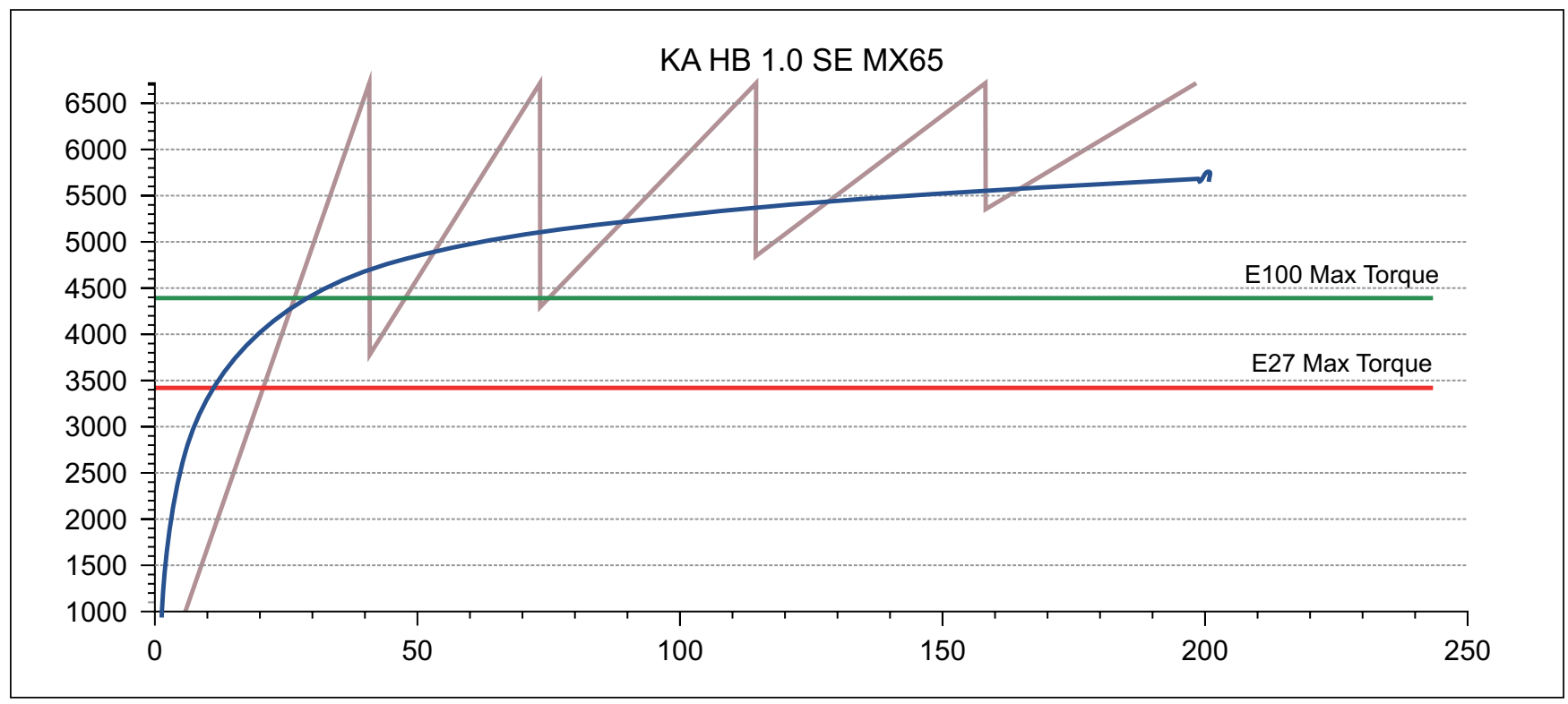

Source: Adapted from Autoentusiastas” 2018;September 30. 


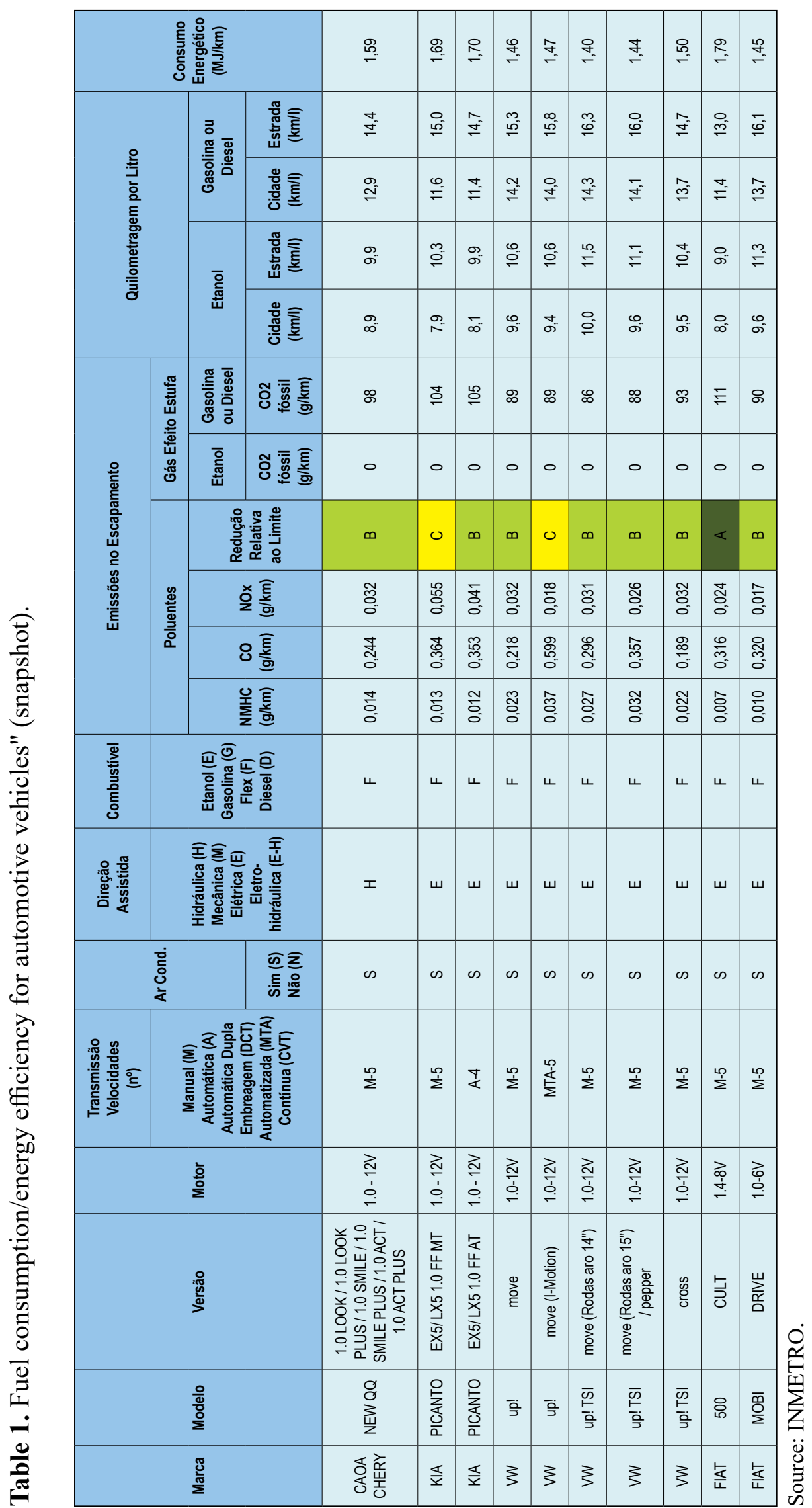


In both "scatter plot" graphs we can see that CVT transmission presents the lowest consumption result for the city cycle in both Ethanol and Gasoline when compared to planetary transmissions. In the road cycle, the CVT achieves consumption values similar to the best Planetary transmission (A7 - 7 gears) when using Ethanol and is among the lowest consumptions for the road cycle when using Gasoline.

\section{Conclusion}

Through our study we were able to conclude: 1) Based on a summary of INMETRO Homologation data for fuel consumption, energy efficiency, and exhaust emissions for PL6 (Brazilian market in the last 10 years), CVT has been showing an advantage about the fuel consumption, but planetary transmissions launched in the last years it has been showing good consumption figures in "Highways", and like the "Dashboard", we will be able to expand it to other vehicles and markets that use homologation tables similar to those used in Brazil. 2) Further work may provide a view of the Brazilian market, its competitors, and what are the trends in the short and medium term.

\section{References}

1. Arbex A. Sistema para simulação de um banco de testes para transmissão veicular automática. Universidade Estadual Paulista 2008.

2. Beltrão C. Da Vinci: Monalisa, Homem Vitruviano, Ornitóptero. CVT. Blog ArtenaRede, Rio de Janeiro, 21 Abril, 2015. Disponível em: < http://artenarede.com.br/ blog/index.php/da-vinci-monalisa-homem-vitruvianoornitoptero-cvt/ > . Acesso em: 14 Jan. 2021.

3. Bonsen B, Steinbuch M, Veenhuizen PA. CVT ratio control strategy optimization. In: 2005 IEEE Vehicle Power and Propulsion Conference. IEEE, 2005. p. 5 pp.

4. Brasil. Contribuição nacionalmente determinada para consecução do objetivo da Convenção-Quadro das Nações Unidas sobre Mudança do Clima. Brasília, DF: Centro Gráfico, 2016. Disponível em: < https://bit. ly/1Ru0Jm3 > . Acesso em: 27 de nov. de 2020.

5. Brasil. Lei $\mathrm{N}^{\mathrm{o}} 13.755$, de 10 de dezembro de 2018. Estabelece requisitos obrigatórios para a comercialização de veículos no Brasil; institui o

Graphic 2. Ethanol fuel consumption average scatter plot.

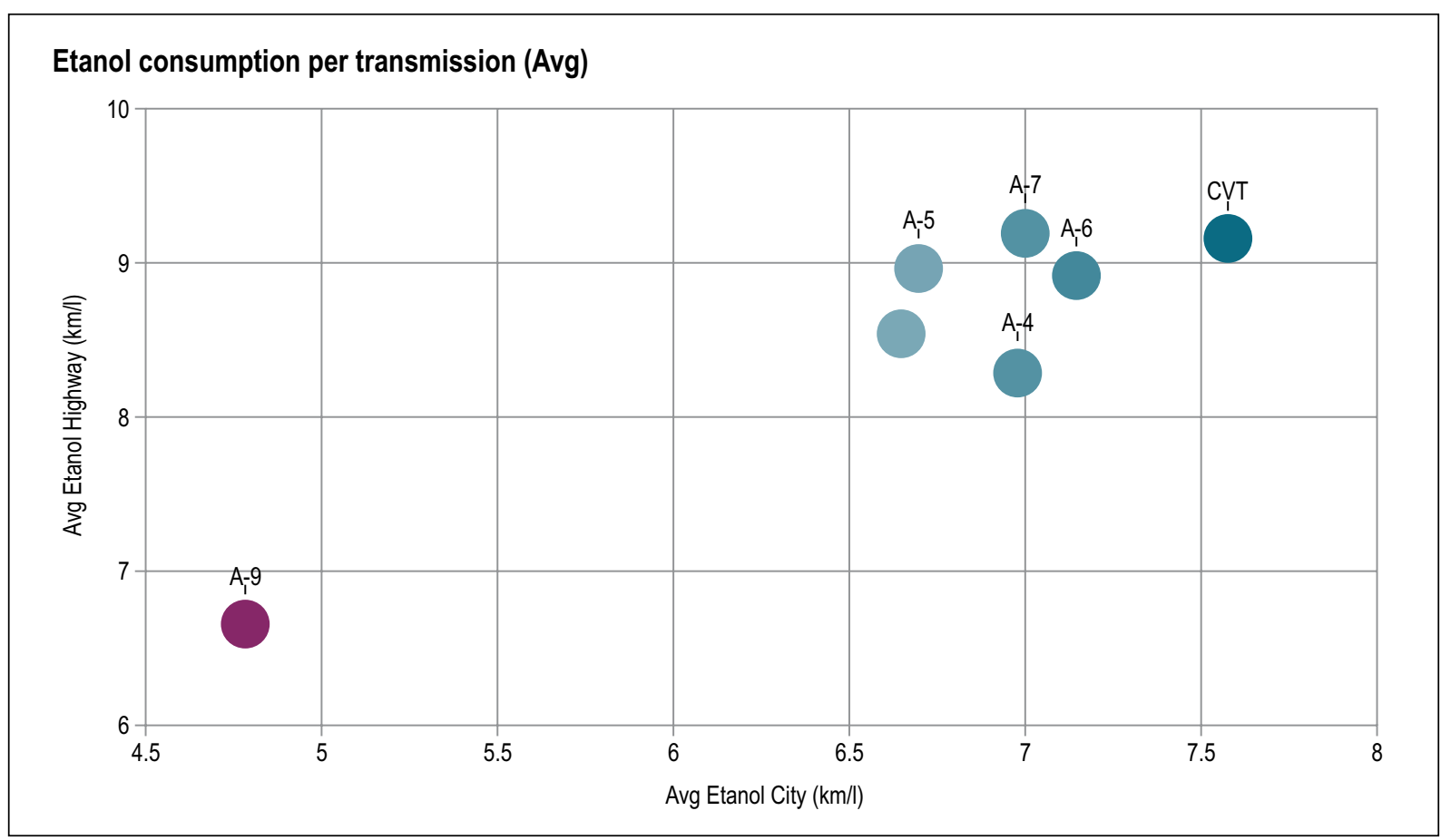


Graphic 3. Gasoline fuel consumption average scatter plot.

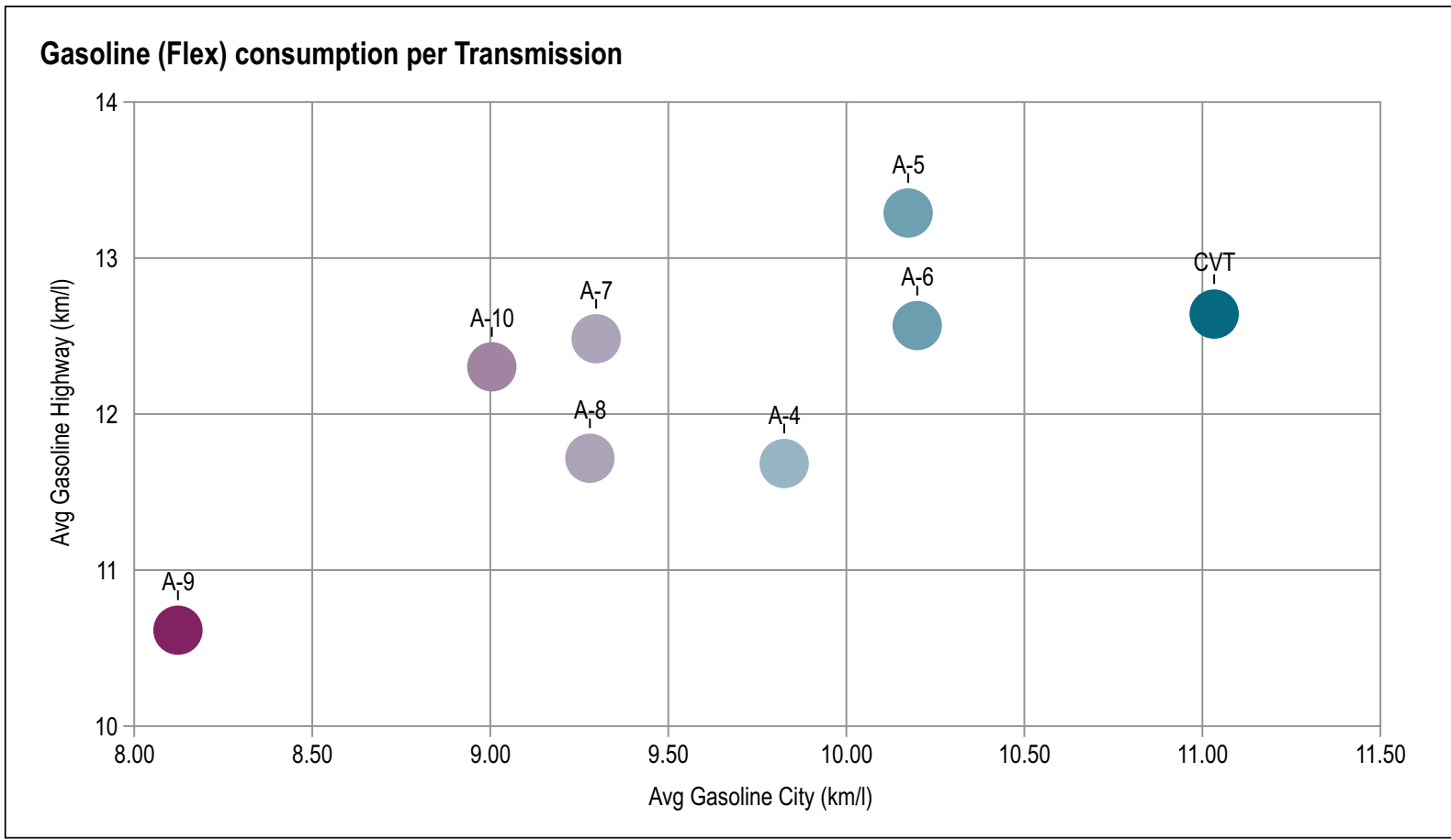

Programa Rota 2030 - Mobilidade e Logística; dispõe sobre o regime tributário de autopeças não produzidas e dá outras providências. Disponível em: $<$ http://www. planalto.gov.br/ccivil_03/_Ato2015-2018/2018/Lei/ L13755.htm> . Acesso em: 30 out. 2020.

6. Dias J. Curso de especialização em Engenharia Automotiva. Universidade Tecnológica Federal do Paraná, Março, 2011.Disponível em: < http://damec. ct.utfpr.edu.br/automotiva/downloadsAutomot/ c2CVT.pdf > Acesso em: 28 Jan 2020.

7. Fanton F, Lima D. Estudo da transmissão continuamente variável CVT de polias expansivas. Ilha Solteira, 2008.

8. Hearst Autos Research. What is an Automatic Car? Revista Car and Driver. 2020. Disponível em: < https:// www.caranddriver.com/research/a31884931/what-isan-automatic-car > . Accessed on: 22 Abril 2021.

9. Heywood JB. Internal combustion engine fundamentals. McGraw-Hill Education, 2018.

10. Yu-Guanga CHEN, et al. Simulation Research for the Dynamic Regulation of Car Running Condition Domains. Journal of Chongqing University of Technology (Natural Science), 2012:11.

11. IMETRO. Tabela PBE para veículos leves: 2019. Disponível em: $<$ http://www. inmetro.gov.br/consumidor/ pbe/veiculos leves2019.pdf> . Acesso em: 09 nov. 2020.

12. IPEA. Cadernos ODS: ODS 13. Disponível em: < http://www.ipea.gov.br/ portal/Images/stories/PDFs/ livros/livros/191014 cadernos ODS objetivo 13.pdf >. Acesso em: 30 out. 2020.

13. Inukai $\mathrm{K}$, et al. Development of high-efficiency new CVT for midsize vehicle. SAE Technical Paper, 2013.

14. Ji J, He B, Yuan L. A comparative study on fuel economy for CVT and 9-speed AT based vehicles. SAE Technical Paper 2017.

15. Jiang F, Wang M Li L. Software Design of Engine Characteristic Simulation. JSW 2012.(7)2:316-321.

16. Lechner $G$, Naunheimer $H$. Fahrzeuggetriebe Grundlagen, Auswahl, Auslegung und Konstruktion. Berlin: Springer - Verlag, 1994.

17. LearnEngineering, YouTube, 2017: < https://www. youtube.com/watch? $\mathrm{v}=\mathrm{ARd}-\mathrm{Om} 2 \mathrm{VyiE}>$ acesso em 10 Maio 2021.

18. Krestschmer, J. e Kara, A.: The new 8-speed automatic transmission, ResearchGate, 2009. Disponível em: < https://www.researchgate.net/publication/293164231 The_new_BMW_8-speed_automatic_transmission > . Acesso em: 18 nov. 2020.

19. Kushwaha GS, Sharma NK. Green initiatives: a step towards sustainable development and firm's performance in the automobile industry. Journal of Cleaner Production 2016;121:116-129.

20. Kwak Y, Cleveland C. Continuously variable transmission (CVT) fuel economy. SAE Technical Paper 2017. 
21. Lanzarotto D, et al. Overview of different hybrid vehicle architectures. IFAC-PapersOnLine 2018;(51)9:218222.

22. Macor A, Rossetti A. Fuel consumption reduction in urban buses by using power split transmissions. Energy Conversion and Management 2013;71:159-171.

23. Mayet $\mathrm{C}$, et al. Influence of a CVT on the fuel consumption of a parallel medium-duty electric hybrid truck. Mathematics and Computers in Simulation 2019;158:120-129.

24. Michkoshi Y, et al. Toyota new TNGA high-efficiency eight-speed automatic transmission direct shift-8AT for FWD vehicles. SAE Technical Paper 2017.

25. Micklem JD, Longmore DK, Burrows CR. Modelling of the steel pushing V-belt continuously variable transmission. Proceedings of the Institution of Mechanical Engineers, Part C: Journal of Mechanical Engineering Science 1994;208(1):13-27.

26. McIntosh JIL. How it works: Automatic transmissions. Disponível em https://driving. ca/auto-news/news/how-it-works-automatictransmissions. Acesso em: 04 Maio 2021. 27. Nakata Automotiva. Entenda tudo que acontece com o Sistema de transmissão do seu carro, 2020. Disponível em: < https://blog.nakata.com.br/entendatudo-que-acontece-com-o-sistema-de-transmissao-doseu-carro/> , acessado em: 17 Maio, 2021.

28. Nice K. How torque converters work. How stuff works. 2021. Disponível em: < https://auto.howstuffworks. com/auto-parts/towing/towing-capacity/information/ torque-converter.htm $>$. Acesso em 18 de Maio de 2021.

29. Noce T, et al. Energy factors for flexible fuel engines and vehicles operating with gasoline-ethanol blends. Transportation Research Part D: Transport and
Environment, v. 65, p. 368-374, 2018.Disponivel em: < https://doi.org/10.1016/j.trd.2018.09.002> , acessado em: 06 Set. 2020.

30. Pfiffner R, Guzzella L, Onder CH. Fueloptimal control of CVT powertrains. IFAC Proceedings Volumes 2001;34(1):17-22. 31. Sharp B. Ford Ka 1.0 SE em teste no uso. Revista Autoentusiastas. 2018. Disponível em: < https:// autoentusiastas.com.br/2018/09/ford-ka-10-em-testeno-uso-com-video $>$. Acessado em: 27 jan 2020.

32. Sun $\mathrm{S}$, et al. Vehicle emissions in a middle-sized city of China: Current status and future trends. Environment International 2020;137:105514.

33. Srivastava N, Haque I. A review on belt and chain continuously variable transmissions (CVT): Dynamics and control. Mechanism and Machine Theory 2009;(44)1:19-41.

34. Tang T-Q, et al. A fuel-optimal driving strategy for a single vehicle with CVT. Physica A: Statistical Mechanics and Its Applications 2018;505:114-123.

35. Thorne C. CVT Transmission: A Platform Technology for On and Off-Road Hauling Applications. SAE Technical Paper, 2017. Disponível em: < https://doi. org/10.4271/2017-01-1930 >. Acesso em: 30 out. 2020.

36. Tracy D. This is how an automatic transmission works. Disponível em < https://jalopnik.com/this-is-how-anautomatic-transmission-works-517581894>. Acesso em 14 Maio de 2021.

37. Tsuji T, Takeoka M. Study of fuel consumption improvement of the car with the dry hybrid belt CVT. JSAE Review 1996;17(4):381-385.

38. Greene DL, Schafer A. Reducing greenhouse gas emissions from US transportation. Pew Center on Global Climate Change. Estados Unidos, 2003. 